\title{
The Use of Real-Time PCR (qPCR) for the Diagnosis of Bovine Herpes virus 5 in Formalin-Fixed, Paraffin-Embedded Bovine Brain Samples Identified as Bovine Unspecific Encephalitis
}

Francisco Pedraza-Ordoñez ${ }^{1,5 *}$, Ricardo Seiti Yamatogi ${ }^{2,3}$, Joao Pessoa Araujo Jr. ${ }^{2,3}$, Noeme Sousa Rocha ${ }^{3,4}$ and Antonio Carlos Aless

${ }^{1}$ Department of Veterinary Pathology, Agricultural and Veterinary Science Faculty, FCAV-UNESP, Jaboticabal, SP, Brazil

${ }^{2}$ Department of Immunology and Microbiology, Institute of Biosciences, São Paulo State University IBB-UNESP, Botucatu, SP, Brazil

${ }^{3}$ School of Veterinary Medicine and Animal Science, Sao Paulo State University, FMVZ-UNESP, Botucatu, SP, Brazil

${ }^{4}$ Department of Pathology, Botucatu Medical School, Sao Paulo State University, FMB-UNESP, Botucatu, SP, Brazil

${ }^{5}$ Animal Health Department, Faculty of Agricultural Sciences, Universidad de Caldas, Manizales, Colombia

\begin{abstract}
Background: Bovine herpes virus 5 (BoHV-5) is a neurovirulent alpha herpes virus that causes fatal meningoencephalitis and huge economic losses in the livestock and associated industries worldwide; its diagnosis in the laboratory is essential for disease control, immunologic surveillance and effective monitoring programs in endemic areas.

Materials and Methods: In this study, brain samples from 21 Colombian cattle that died of neurological disease, were negative for rabies and were diagnosed with nonspecific encephalitis were processed by real-time PCR (qPCR) in the laboratory of virology at the Institute of Biosciences, Sao Paulo State University, Brazil, to detect BoHV-5 genetic material in tissue preserved in paraffin blocks. Tissues were considered positive for BoHV-5 if amplification occurred at or before 30 PCR cycles, inconclusive if amplification occurred between 30 and 40 cycles and negative otherwise.

Results and Conclusion: Two cases were positive, demonstrating that qPCR may be useful for confirming herpes encephalitis in acid formalin-fixed tissues with an inconclusive diagnosis.
\end{abstract}

Keywords: Bovine Herpes virus 5; Real-Time PCR; Diagnosis; BoHV-5

Abbreviations: qPCR: Real-time PCR; BoHV-5: Bovine Herpes Virus 5; BoHV-1: Bovine Herpes virus 1; gC: Glycoprotein C; Us9: Protein Us9; $a$-tif: Protein a-tif; BSE: Bovine Spongiform Encephalopathy; vCJD: Creutzfeldt-Jakob Disease; ICA: Colombian Agricultural Institute

\section{Background}

Bovine herpes virus 5 (BoHV-5), known as bovine encephalitis herpes virus, is a neurovirulent alpha herpes virus that causes fatal meningoencephalitis in calves and significant economic losses in the cattle industry. This virus may also be associated with bovine herpes virus 1 (BoHV-1), which commonly affects the respiratory and reproductive systems of the same host [1-3]. Molecularly, the envelope of BoHV-5 is formed by the glycoproteins $\mathrm{gB}, \mathrm{gC}, \mathrm{gD}, \mathrm{gE}, \mathrm{gG}, \mathrm{gK}, \mathrm{gH}, \mathrm{gI}, \mathrm{gL}$ and $\mathrm{gM}$ and the proteins Us9 and $\alpha$-tif. The gC protein has been associated with the introduction of the virus in the brain, and $\mathrm{gD}$ is the receptor that facilitates binding to the host cell, initiating a replication process similar to those of other alpha herpes viruses [4-8]. Although present in both BoHV-1 and BoHV-5, the gE amino acid sequence differs significantly between these viruses, causing a major difference in the nervous system invasion pattern and latency of BoHV-1 and BoHV-5 [4,6]. The Us9 protein of BoHV-1 is crucial for reactivation in the trigeminal ganglia, and the same protein in BoHV-5 has an important role in viral transport from olfactory receptor neurons to the olfactory bulb [9]. From an epidemiological standpoint, a viral neutralization test against BoHV1 can be useful for suspected infection with BoHV-5 [10]; however, because they share many structural, biological, antigenic and molecular characteristics, cross-reactions may occur between the two viruses, which hinder the evaluation of their serological prevalence [11-13].

BoHV-5 is transmitted by direct contact with contaminated aerosols, fomites or even semen [14]. It can affect animals of any breed, sex and age, but calves are more susceptible $[1,15]$. There is a high mortality rate; however, some animals recover [16].

BoHV-5 infection is clinically characterized by depression, anorexia, isolation from the flock, serous ocular secretion and nasal discharge, drooling, muscle tremors that are most evident in the head and neck, hyperesthesia and loss of vision [17-19]. Infection also leads to walking in circles, ataxia, trismus, hypotonia of the tongue, difficulty in drinking water, nystagmus, bruxism, catatonia, prolonged decubitus, pedaling movements and death $[1,11,20]$.

Many etiological agents, namely bacteria, viruses, toxins, pesticides, and nutritional and metabolic imbalances (mineral deficiency or toxicity), may cause nervous disorders in cattle; BoHV-5 is often misdiagnosed as herpetic meningoencephalitis, resulting in inadequate epidemiological analysis [21]. Among the diseases to be considered in the differential diagnosis of BoHV-5 are rabies, polioencephalomalacia/ thiamine deficiency, bacterial meningitis, acute lead poisoning, botulism and bovine spongiform encephalopathy (BSE) [14,22,23].

*Corresponding author: Francisco Pedraza-Ordoñez, Department of Veterinary Pathology, Agricultural and Veterinary Science Faculty, FCAV-UNESP, Jaboticabal, SP, Brazil, E-mail: fpedraza@ucaldas.edu.co

Received July 09, 2013; Accepted October 10, 2013; Published October 14 2013

Citation: Pedraza-Ordoñez F, Yamatogi RS, Araujo Jr JP, Rocha NS, Alessi AC (2013) The Use of Real-Time PCR (qPCR) for the Diagnosis of Bovine Herpes virus 5 in Formalin-Fixed, Paraffin-Embedded Bovine Brain Samples Identified as Bovine Unspecific Encephalitis. J Veterinar Sci Technol 4: 145. doi:10.4172/21577579.1000145

Copyright: (C) 2013 Pedraza-Ordoñez F, et al. This is an open-access article distributed under the terms of the Creative Commons Attribution License, which permits unrestricted use, distribution, and reproduction in any medium, provided the original author and source are credited. 
Citation: Pedraza-Ordoñez F, Yamatogi RS, Araujo Jr JP, Rocha NS, Alessi AC (2013) The Use of Real-Time PCR (qPCR) for the Diagnosis of Bovine Herpes virus 5 in Formalin-Fixed, Paraffin-Embedded Bovine Brain Samples Identified as Bovine Unspecific Encephalitis. J Veterinar Sci Technol 4: 145. doi:10.4172/2157-7579.1000145

Page 2 of 5

Histopathologically, intranuclear inclusion bodies in astrocytes and neurons, although not always found, can help diagnose of BoHV-5 $[16,24]$. More sophisticated techniques, such as viral isolation from brain samples and nasal secretions, the use of fluorescent antibodies and immunohistochemistry, can confirm the diagnosis of the disease, but the quality of the sample and the use of preservatives prior to its arrival to the laboratory can affect the accuracy of these assays $[13,25]$. The quality of the diagnosis is usually directly related to the quality of samples submitted to the diagnostic laboratory; the correct specimens must be collected, preserved and submitted to the laboratory in a timely fashion [26,27]. In many cases, formalin is used to fix the tissue, and although formalin fixation is excellent for routine histopathology, it usually inactivates the virus and hinders its detection using molecular tests because it alters the reactivity of antigens and masks antigenic determinants [20]. Molecular techniques, such as polymerase chain reaction (PCR), can be used to detect the virus and differentiate it from BoHV-1 in field samples or laboratory experiments $[14,28]$. The purpose of this study was to use real-time PCR (qPCR) to identify the bovine encephalitis herpes virus in natural cases of bovine nervous disease that were negative for rabies and were identified in the laboratory as nonspecific encephalitis.

\section{Materials and Methods}

\section{Paraffin-embedded brain tissue}

A retrospective study was conducted using twenty-one formalinfixed, paraffin-embedded brain samples from Colombian cattle with non-suppurative encephalitis. Paraffin blocks of tissue from cases that occurred between 2000 and 2009 were obtainedwith permission from the National Veterinary Diagnostic Laboratory of the Colombian Agricultural Institute (ICA) in Bogotá and Monteria. The samples were fixed in $10 \%$ formalin prior to embedding, but it was not clear how long the materials had remained in the fixative; estimates ranged from several days to over one year. The samples were processed by conventional methods for histological analysis and stained with hematoxylineosin. The samples were selected from two hundred and ten cases negative for rabies disease (by indirect immunofluorescence test) using histopathological criteria compatible with BoHV-5 infection, such as perivascular cuffing, mononuclear cell infiltration, areas of malacia and gitter cells (macrophages) and intranuclear inclusion bodies. The cases analyzed were Zebu or Zebu cross-breed males and females, aged between six months and five years, with clinical symptoms of

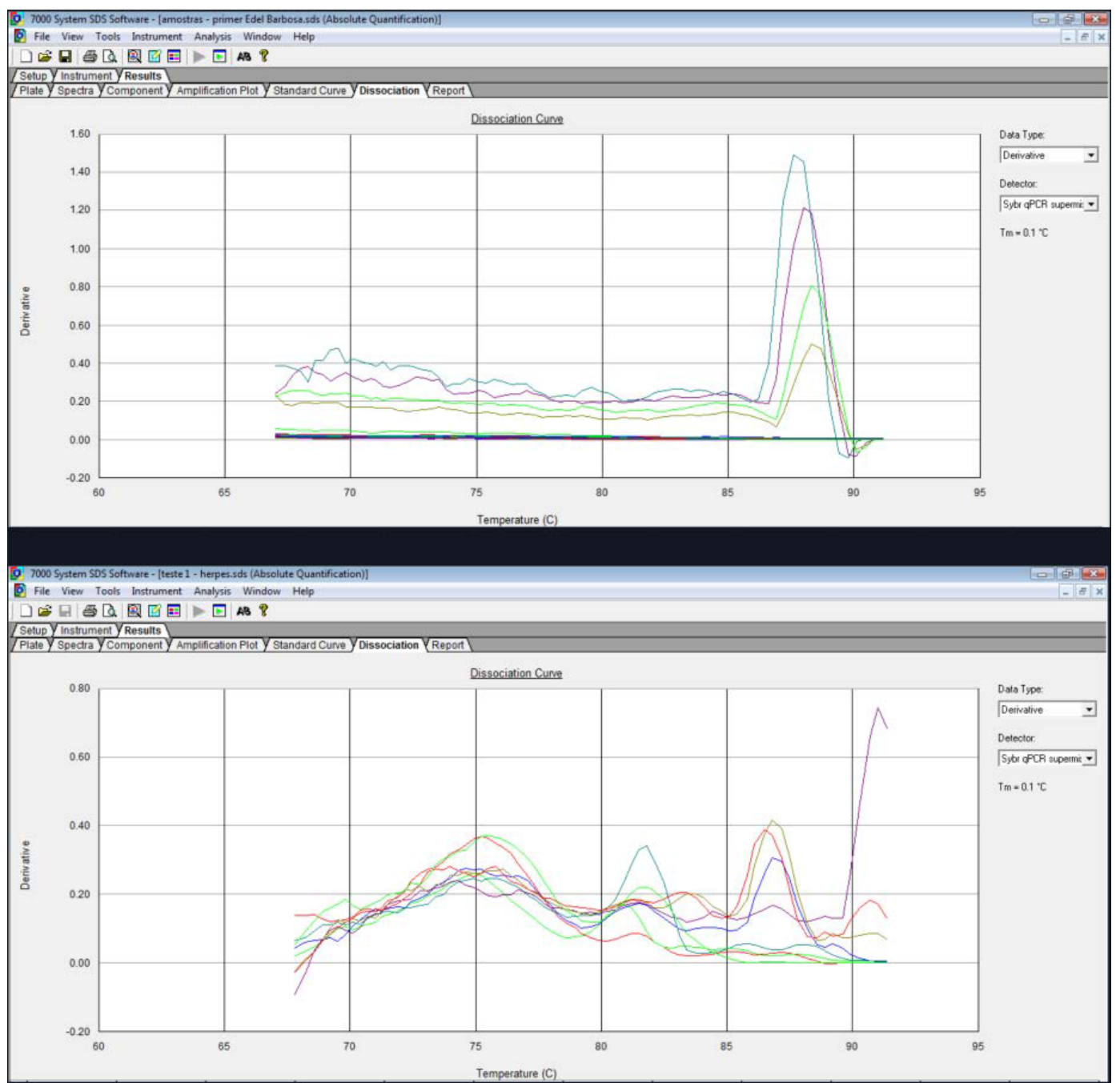

Figure 1: Real-time PCR (qPCR) for Bovine Herpesvirus 5 (BoHV-5) using two different primers. The upper panel shows positive cases identified by qPCR with primers suggested by Gomes et al. (2002), including two controls and two samples. The lower panel shows qPCR using the primers suggested by Campos et al. (2009). Note the number of nonspecific peaks, which preclude the positive identification of the cases analyzed. 
Citation: Pedraza-Ordoñez F, Yamatogi RS, Araujo Jr JP, Rocha NS, Alessi AC (2013) The Use of Real-Time PCR (qPCR) for the Diagnosis of Bovine Herpes virus 5 in Formalin-Fixed, Paraffin-Embedded Bovine Brain Samples Identified as Bovine Unspecific Encephalitis. J Veterinar Sci Technol 4: 145. doi:10.4172/2157-7579.1000145

neurological disease. A post-mortem diagnosis of non-suppurative encephalitis was possible with microscopic examination.

\section{Real-time PCR (qPCR)}

6.2.1 DNA extraction: The Illustra TM Tissue \& Cells genomic Prep Mini Spin Kit (GE Healthcare Life Sciences, Pittsburgh, Pennsylvania, USA) was used for the extraction of total genetic material from paraffinembedded tissues according to the manufacturer's instructions. To evaluate a possible cross-reaction, two blank reactions (no reagent, only samples) were obtained from each group of 10 paraffin tissue sections. Finally, the DNA concentration was determined by reading the optical density at $260 \mathrm{~nm}$.

Sample processing: We tested two primer pairs to detect BoHV-5: sense, TACGGACTGCCGGATTAACA, and anti-sense, GTCACCACTA CCACCGCCGCCA ACAT, as suggested by Gomes et al. [31]; and sense, PF 5'-GTGGAGCGCCGCTTCGC-3', and antisense, PR 5'-TATCGCGGAGAGCAGGCG-3', as suggested by Campos et al. [30]. Of the 21 DNA samples extracted from the bovine brain tissues, five had already been evaluated with positive results for BoHV5 by nested PCR [34].

For qPCR, we used $400 \mathrm{nmol}$ of each primer, $10 \mu \mathrm{L}$ of $2 \mathrm{X}$ Power $\mathrm{SYBR}^{\bullet}$ Green PCR Master Mix (Promega, USA), $4 \mu \mathrm{L}$ of DNA extract from samples, and nuclease-free water to a final volume of $20 \mu \mathrm{L}$. The reaction conditions were as follows: $95^{\circ} \mathrm{C} / 10$ minutes for the initial denaturation, 40 amplification cycles $\left(95^{\circ} \mathrm{C}\right.$ for $15 \mathrm{~s}$ for denaturation and $60^{\circ} \mathrm{C}$ for 1 minute for annealing and extension), and a melting curve analysis. The fluorescence data were collected during the annealing and extension steps, and the threshold cycle numbers (CT) were determined using an ABI PRISM ${ }^{\circ} 7300$ Sequence Detector (Applied Biosystems, USA) and SDS software version 1.2.3 (Sequence Detection Systems 1.2.3, 7300 Real Time PCR System; Applied Biosystems, USA). As a negative control, the sample was replaced with nuclease-free water; as a positive control, a DNA sample extracted from tissue with positive immunohistochemistry and nested PCR results was used. All of the reactions were performed in duplicate.

The $\beta$-actin gene (GenBank: NM 173979.3) was included as an internal control to demonstrate the presence of bovine DNA in the samples and verify the efficiency of the extraction process.

Analytical sensitivity and specificity assay: For analytical sensitivity assay, a DNA fromcell culture containing $10^{7} \mathrm{TCID}_{50}$ (tissue culture infectious doses) was extract according to described above. Tenfold serial dilutions of purified DNA were used as template in qPCR The analytical specificity assay was made using 4 agents: Canine Herpes virus type 1, Neospora caninum, Human Herpes virus type 4 - Epstein Barr and Human Herpes virus type 8 - Kaposi Sarcoma.

\section{Results and Discussion}

qPCR has revolutionized the laboratory diagnosis of human diseases [29], but to our knowledge, it has not yet been used for the diagnosis of bovine herpes virus. In the present study, BoHV-5 DNA was detected by qPCR in two samples among all of the cases analyzed, demonstrating the usefulness of this technique as an aid in the diagnosis of BoHV infection in cattle with clinical symptoms of neurological disease, even in samples that are stored in acid formalin for long periods. The primers suggested by Campos et al. [30] did not perform well and presented several nonspecific peaks for detection of the virus; therefore, they were not used in this work. However, the primers proposed by Gomes et al. [31] resulted in well-defined peaks in four positive cases (including the two controls). In the analytical sensitivity the qPCR showed positive results until $1 \mathrm{TCID}_{50}$. In specifity assay no agent tested was positive. The difference in performance between the primers can be related to several factors, such as the amplification mix used, the quality of the extracted genetic material or even the characteristics of the initiator. The comparison between the two types of primers is shown in Figure 1.

\begin{tabular}{|c|c|c|c|c|c|c|c|}
\hline Case & Age (months) & Sex & Municipality & Micro & Macro & Nested PCR* & qPCR \\
\hline 0014 & $>24$ & No data & Planeta Rica & No significant lesions & No data & - & - \\
\hline 0105 & 60 & Female & La Ceja & Perivascular cuffing & Bruxism, ptyalism & - & - \\
\hline 0151 & 30 & Male & Tulua & Inclusion bodies & Blind, recumbency & - & - \\
\hline 0212 & 24 & Male & Monteria & Non suppurative meningoencephalitis & Recumbency, opisthotonos & Positive BoHV-5 & Positive BoHV-5 \\
\hline 0303 & 48 & Male & Valledupar & No data & Hyperexcitability, no menace reflex & - & - \\
\hline 0310 & 6 & Male & Bucaramanga & Meningitis & Ptyalism, bruxism, circling & Positive BoHV-5 & - \\
\hline 0324 & 8 & Male & Valledupar & Congestion, hemorrhage & Found dead & Positive BoHV-5 & - \\
\hline 0413 & 19 & Female & Palmira & Meningitis and congestion & circling, recumbency & - & - \\
\hline 0669 & $>24$ & No data & Monteria & Edema, congestion & No data & - & - \\
\hline 0853 & $>24$ & No data & Tierra Alta & Perivascular cuffing, gliosis & No data & - & - \\
\hline 0854 & $>24$ & No data & $\begin{array}{l}\text { Cienaga } \\
\text { de Oro }\end{array}$ & $\begin{array}{l}\text { Gliosis, edema, congestion, } \\
\text { perivascular cuffing }\end{array}$ & No data & - & - \\
\hline 0878 & 18 & Male & Valledupar & Perivascular cuffing & Recumbency, opisthotonos & Positive BoHV-5 & - \\
\hline 0904 & 23 & Female & La Dorada & Meningitis & Blind, circling, recumbency & - & - \\
\hline 0945 & $>24$ & No data & Puerto Libertador & Edema, congestion, hemorrhage & No data & - & - \\
\hline 0949 & $>24$ & No data & Montelibano & Edema. & No data & - & - \\
\hline 1014 & 9 & Female & Sincelejo & Perivascular cuffing & Ptyalism, bruxism, recumbency & Positive BoHV-5 & Positive BoHV-5 \\
\hline 1029 & 51 & Female & Puerto Tejada & Meningitis & Found dead & - & - \\
\hline 1044 & 42 & Male & Valledupar & Non suppurative meningoencephalitis & circling, recumbency, opisthotonos & - & - \\
\hline 1697 & $>24$ & No data & Monteria & Gliosis, edema, congestion, malacia & No data & - & - \\
\hline 1824 & $>24$ & No data & Monteria & Gliosis, edema, satellitosis & No data & - & - \\
\hline 0454 & $>24$ & No data & No data & $\begin{array}{l}\text { Edema, gitter cells, congestion, } \\
\text { perivascular cuffing }\end{array}$ & No data & - & - \\
\hline
\end{tabular}

* Pedraza et al. (2010) [28].

Table 1: Major clinicopathological findings in cattle affected with nonspecific encephalitis identified as BoHV-5 positive by qPCR 
Citation: Pedraza-Ordoñez F, Yamatogi RS, Araujo Jr JP, Rocha NS, Alessi AC (2013) The Use of Real-Time PCR (qPCR) for the Diagnosis of Bovine Herpes virus 5 in Formalin-Fixed, Paraffin-Embedded Bovine Brain Samples Identified as Bovine Unspecific Encephalitis. J Veterinar Sci Technol 4: 145. doi:10.4172/2157-7579.1000145

PCR has been used several times to determine the presence of virus in tissue from in natural cases maintained in paraffin blocks. In a retrospective study, Ely et al. [32] found seven positive cases of BoHV-5 and one positive case of BoHV-1 by PCR in thirty-two cases classified as non-specific encephalitis and negative for rabies. Ferrari et al. [33] detected fifteen positive samples by PCR in twenty naturally infected cattle in which half of the brain was used fresh for virus isolation and the other half was fixed in $10 \%$ buffered formalin for an average of one week prior to PCR. Gomes et al. [31] found two positive cases among three samples tested by nested PCR. Pedraza et al. [34] found five positive cases among fifteen samples tested using nested PCR (Table 1).

In our study, possibly because the samples were kept in acid formalin for very long periods, the amplification of viral DNA was limited in cases with morphological alterations characteristic of infection with bovine herpes virus. The two positive cases might correspond to samples that were maintained in formalin for a short time or that contained a large amount of virus, which would have facilitated its detection in qPCR. Another important result was the difference between tests. Two samples tested positive for BoHV- 5 by qPCR, while five tested positive by the nested PCR performed by Pedraza et al. [34]. This difference may be due to several factors, including the greater sensitivity of nested PCR compared to qPCR. In the previous study, the first product of the nested PCR showed no positive results, and positivity was detected in the five cases only in the second amplification [34]. Because two positive results were achieved by qPCR in a single amplification (suggesting good test sensitivity), using nested qPCR could identify a larger number of positive cases.

Since bovine spongiform encephalopathy (BSE) and its subsequent association with variant Creutzfeldt-Jakob disease (vCJD) were identified in the last century, the socio-economic and public health importance of research in bovine encephalitis has increased [35]. The diagnosis of the causes of illness or death affecting cattle is of fundamental importance for the rapid implementation of preventive methods; however, there are often challenges in sending samples to the laboratory. In Brazil, for example, in a study of 496 cases of nervous disease in cattle, it was impossible to achieve a conclusive diagnosis due to poor sample collection or preservation in $68.35 \%$ of the cases [22]. This limitation, coupled with the fact that it is difficult to serologically differentiate between BoHV-1 and BoHV-5, has caused the under-diagnosis of bovine herpetic encephalitis in several regions of South America [10]. Several studies have proposed the use of molecular techniques to help differentiate between the two viruses, including PCR, which is specific and practical and has the advantage of allowing retrospective studies of samples fixed in formalin and preserved in paraffin [3,32,36,37]. Other techniques, such as immunohistochemistry, have also been suggested as useful tools in cases that were closed without a specific diagnosis $[25,38-40]$.

In this work, we showed that $\mathrm{qPCR}$ is a useful technique for the molecular detection of BoHV-5 in formalin-fixed and paraffinembedded brain samples. We propose its use for the identification of positive cases that have a diagnosis of nonspecific encephalitis, thus contributing to the accurate epidemiological mapping of bovine encephalitis in several regions of the world.

\section{Conclusions}

BoHV-5 DNA was detected by qPCR in two samples among all of the cases analyzed, demonstrating the usefulness of this technique as an aid in the diagnosis of BoHV infection in cattle with clinical symptoms of neurological disease, even in samples that are stored in acid formalin for long periods. The identification of BoHV-5 positive cases that have a diagnosis of nonspecific encephalitis, contributes to the accurate epidemiological mapping of bovine encephalitis in several regions of the world.

\section{Author's Contributions}

Francisco Pedraza-Ordoñez: Data collecting and writing of the manuscript.

Ricardo Seiti Yamatogi, Joao Pessoa Araujo Jr.: qPCR analysis and critical review of the manuscript.

Noeme Sousa Rocha and Antonio Carlos Alessi: Analysis and interpretation of data, making and critical review of the manuscript.

\section{Competing Interest}

None of the authors of the present document has conflict of interest for its publication.

\section{Acknowledgements}

The authors would like to extend their gratitude to Dr. Dario Mogollon of the Colombian Agricultural Institute (ICA) for providing the samples and Prof. Dr Alexandre Secorun Borges of UNESP, Botucatu, Brazil, for providing the bovine qPCR internal control.

\section{References}

1. Colodel EM, Nakasato L, Weiblen R, Mello RM, Silva RRP, et al. (2002) Necrotizing meningoencephalitis in cattle caused by bovine herpesvirus in Mato Grosso, Brazil. Ciência Rural Santa Maria 32: 293-298.

2. Fields BN, Knipe DM, Howlay PM (1996) Fundamental Virology. (3nd Edn) Raven Press.

3. Silva MS, Brum MC, Loreto EL, Weiblen R, Flores EF (2007) Molecular and antigenic characterization of Brazilian bovine herpesvirus type 1 isolates recovered from the brain of cattle with neurological disease. Virus Res 129 191-199.

4. Chowdhury SI, Onderci M, Bhattacharjee PS, Al-Mubarak A, Weiss ML et al. (2002) Bovine herpesvirus 5 (BHV-5) Us9 is essential for BHV-5 neuropathogenesis. J Virol 76: 3839-3851.

5. Delhon G, Moraes MP, Lu Z, Afonso CL, Flores EF, et al. (2003) Genome of bovine herpesvirus 5. J Virol 77: 10339-10347.

6. Gabev E, Tobler K, Abril C, Hilbe M, Senn C, et al. (2010) Glycoprotein D of bovine herpesvirus 5 (BoHV-5) confers an extended host range to BoHV-1 but does not contribute to invasion of the brain. J Virol 84: 5583-5593.

7. Gillette K, Misra V, Bratanich A (2002) Sequence analysis of the alpha transinducing factor of bovine herpesvirus type 5 (BHV-5). Virus Genes 24: 149-152.

8. Meyer G, Lemaire M, Lyaku J, Pastoret PP, Thiry E (1996) Establishment of a rabbit model for bovine herpesvirus type 5 neurological acute infection. Vet Microbiol 51: 27-40.

9. Silva AD, Franco AC, Esteves PA, Spilki FR, Roehe PM (2009) Experimental infection of rabbits with a recombinant bovine herpesvirus type 5 (BoHV-5) gl, gE and Us9-negative. Pesq Vet Bras 29: 913-918.

10. Pedraza FJ, Lopez JP, Avila JA, Alessi AC, Flores EF (2011) Serological evidence of bovine Herpesvirus 5 (BoHV-5) in cattle at the Colombia's eastern plains. Rev Cientif FCV-LUZ 21: 16-21.

11. Beltrão NF, Flores EF, Weiblen R, Silva AM, Roehe PM, et al. (2000) Infection and neurological disease by bovine herpesvirus type 5 (BoHV-5): rabbits as an experimental model. Pesquisa Veterinária Brasileira 20: 144-150.

12. Flores EF, Weiblen R, Vogel FSF, Dezengrini R, Alemida SR, et al. (2009) Neuropathogenesis of experimental infection with bovine herpesvirus type 5 in rabbits. Pesq Vet Bras 29: 1-16

13. Roehe PM, Almeida RS, Teixeira MFB, Esteves PA, Oliveira EAS, et al. (1997) Update in the diagnosis and control of infections Bovine Herpesvirus type 1 (BHV-1) and 5 (BHV-5). The Biological, São Paulo 59: 27-32.

14. Gomes LI, Rocha MA, Souza JG, Costa EA, Barbosa-Stancioli EF (2003) Bovine herpesvirus 5 (BoHV-5) in bull semen: amplification and sequence analysis of the US4 gene. Vet Res Commun 27: 495-504. 
Citation: Pedraza-Ordoñez F, Yamatogi RS, Araujo Jr JP, Rocha NS, Alessi AC (2013) The Use of Real-Time PCR (qPCR) for the Diagnosis of Bovine Herpes virus 5 in Formalin-Fixed, Paraffin-Embedded Bovine Brain Samples Identified as Bovine Unspecific Encephalitis. J Veterinar Sci Technol 4: 145. doi:10.4172/2157-7579.1000145

15. Rissi DR, Oliveira FN, Rech RR, Pierezan F, Lemos RAA, et al. (2006) Epidemiology, clinical signs and distribution of the encephalic lesions in cattle affected by meningoencephalitis caused by bovine herpesvirus-5. Pesq Vet Bras 26: 123-132.

16. Elias F, Schild AL, Riet-Correa F (2004) Meningoencephalitis and encephalomalacia by bovine herpesvirus 5 : distribution of lesions in the central nervous system of cattle naturally infected. Pesq Vet Bras 24: 123-131.

17. Lemos RAA, Barros N, Brum KB (2002) Diseases of economic interest in beef cattle, questions and answers. Campo Grande: Editora Universidade Federal de Mato Grosso do Sul

18. Salvador SC, Lemos RAA, Riet-Correa F, Roehe PM, Osorio AL (1998) Meningoencefalite em bovinos causada por herpesvírus bovino tipo 5 (BHV-5) em Mato Grosso do Sul e Sao Paulo. Pesquisa Veterinária Brasileira 18: 76-83.

19. Vasconcelos RM, Varaschin MS, Wouters F (1993) Meningoencephalitis bovine herpesvirus. In Proceedingsof National Meeting of Veterinary Pathology.

20. Perez SE, Bretschneider G, Leunda MR, Osorio EA, Flores EF, et al. (2002) Primary infection, latency, and reactivation of bovine herpesvirus type 5 in the bovine nervous system. Vet Pathol 39: 437-444.

21. Pedraza FJ, Alessi AC (2004) Encephalitis bovine for herpesvirus bovine type 5 (BHV-5). Rev Col Cienc Pec 17: 148-155.

22. Lemos RAA (2005) Nervous system disorders of beef cattle from the midwestern and southeastern Brazil. PhD thesis. Sao Paulo State University (UNESP-FCAV), Veterinary Pathology Department.

23. Sant'Ana FJF, Barros CS (2010) Polioencephalomalacia in ruminants in Brazil. Brazilian Journal of Veterinary Pathology 3: 70-79.

24. Sanches AW, Langohr IM, Stigger AL (2000) Diseases of the central nervous system in cattle in southern Brazil. Pesq Vet Bras 20: 113-118.

25. Hübner SO, Pescador C, Corbellini LG, Driemeier D, Spilki FR, et al. (2005) Optimization of immunohistochemical detection of bovine herpesvirus type 5 (BHV-5) in central nervous system tissues fixed with formaldehyde. Arq Bras Med Vet Zootec 57: 1-6.

26. D'Amico F, Skarmoutsou E, Stivala F (2009) State of the art in antigen retrieval for immunohistochemistry. J Immunol Methods 341: 1-18

27. Protocol for Postmortem Diagnosis of Rabies in Animals by Direct Fluorescent Antibody Testing. A Minimum Standard for Rabies Diagnosis in the United States.

28. Alegre M, Nanni M, Fondevila N (2001) Development of a multiplex polymerase chain reaction for the differentiation of bovine herpesvirus- 1 and -5 . J Vet Med $B$ Infect Dis Vet Public Health 48: 613-621.
29. Espy MJ, Uhl JR, Sloan LM, Buckwalter SP, Jones MF, et al. (2006) Real-time $\mathrm{PCR}$ in clinical microbiology: applications for routine laboratory testing. Clin Microbiol Rev 19: 165-256.

30. Campos FS, Franco AC, Hübner SO, Oliveira MT, Silva AD, et al. (2009) High prevalence of co-infections with bovine herpesvirus 1 and 5 found in cattle in southern Brazil. Vet Microbiol 139: 67-73.

31. Gomes LI, Rocha MA, Costa EA, Lobato ZIP, Mendes LCN, et al. (2002 Detection of bovine herpesvirus 5 (BoHV-5) in cattle in southeastern Brazil. Arq Med Vet Zoot 54: 1-4.

32. Ely RW, d'Offay JM, Ruefer AH, Cash CY (1996) Bovine herpesviral encephalitis: a retrospective study on archived formalin-fixed, paraffin-embedded brain tissue. J Vet Diagn Invest 8: 487-492.

33. Ferrari HF, Luvizotto MC, Rahal P Cardoso TC (2007) Detection of bovine Herpesvirus type 5 in formalin-fixed, paraffin-embedded bovine brain by PCR: a useful adjunct to conventional tissue-based diagnostic test of bovine encephalitis. J Virol Methods 146: 335-340.

34. Pedraza FJ, Barbosa-Stancioli EF Alessi AC (2010) Detection of bovine herpesvirus 5 (BoHV-5) in formalin-fixed, paraffin-embedded bovine brain by nested PCR in Colombian cattle. Rev Col Cienc Pec 23: 292-298.

35. Barros CSL, Driemeier D, Dutra IS, Lemos RAA (2006) Nervous System Diseases of Cattle in Brazil. Agnes.

36. Ashbaugh SE, Thompson KE, Belknap EB, Schultheiss PC, Chowdhury S, et al. (1997) Specific detection of shedding and latency of bovine herpesvirus 1 and 5 using a nested polymerase chain reaction. J Vet Diagn Invest 9: 387-394

37. Claus MP, Alfieri AF, Folgueras-Flatschart AV, Wosiacki SR, Médici KC, et al. (2005) Rapid detection and differentiation of bovine herpesvirus 1 and 5 glycoprotein $\mathrm{C}$ gene in clinical specimens by multiplex-PCR. J Virol Methods 128: 183-188.

38. Meyer G, Lemaire M, Ros C, Belak K, Gabriel A, et al. (2001) Comparative pathogenesis of acute and latent infections of calves with bovine herpesvirus types 1 and 5. Arch Virol 146: 633-652.

39. Pedraza FJ, Schild AL, Alessi AC (2008) Immunohistochemical description of encephalitis in Brazilian cattle naturally infected with bovine herpesvirus 5 (HVB-5). Arch Med Vet 40: 69-75.

40. Vogel FS, Caron L, Flores EF, Weiblen R, Winkelmann ER, et al. (2003) Distribution of bovine herpesvirus type 5 DNA in the central nervous systems of latently, experimentally infected calves. J Clin Microbiol 41: 4512-4520. 